Tarih Kültür ve Sanat Araştırmaları Dergisi

Revue des Recherches en Histoire Culture et Art مجلة البحوث التاريخية و الثقافية و الفنية
Vol. 7, No. 5, December 2018

Copyright (C) Karabuk University

http://kutaksam.karabuk.edu.tr

\title{
DOI: 10.7596/taksad.v7i5.1664
}

Citation: Sankır, H. (2018). Gündelik Nesnenin Sanatsal Dönüşümü: Sıradan Nesnelerin Sanat Eserine Dönüşüm Süreci Üzerine Sosyolojik Bir Değerlendirme. Journal of History Culture and Art Research, 7(5), 524-543. doi:http://dx.doi.org/10.7596/taksad.v7i5.1664

\section{Gündelik Nesnenin Sanatsal Dönüşümü: Sıradan Nesnelerin Sanat Eserine Dönüşüm Süreci Üzerine Sosyolojik Bir Değerlendirme}

\section{Artistic Transformation of Casual Objects: A Sociological Evaluation on the Process of Transformation of Ordinary Objects into Art}

Hasan Sankır ${ }^{1}$

\begin{abstract}
All products in the art field have a cultural character and reflect the characteristics of the social space in which they are situated. Objects have no meaning in their own rights and all objects, including art objects, acquire its meaning through social construction. In this respect, the meaning of artwork is symbolic and conceptual. The purpose of this work is to reveal how and by what conditions ordinary objects are transformed into artworks by artists. It is aimed to determine which social mechanisms take place in the process of artistic transformation of objects and what the role of social space and artists is in the construction and operation of these mechanisms. For this purpose, the study is composed of two parts. In the first part, how social context of an artwork is being constructed and according to this context how an object and space acquire artistic meaning have been set forth through semiotics approach. In the second part, an approach to the artistic transformation of an ordinary object through the role of artist and construction of social context with the examples selected from the art history have been put forward. In this section, the "bed" was chosen as the ordinary object and a discussion was made about the transformation process of the bed into a work of art through the work of Tracy Emin's "My Bed". As a result of the study, it was understood that ordinary objects have their own unique cultural spaces, and that they have an active role in the social context in which these objects have their meaning. Through the action of the artist towards an artistic goal, it has been specified that at the end of processes such as the removal of an ordinary object from the cultural space and its isolation from its functions, it is possible to change its social context and corresponding meaning. After this process, it has become possible to evaluate the object as an art work with the expansion of its meaning by turning it into an indicator.
\end{abstract}

Keywords: Art Object, Social context, Artistic labeling, Construction of meaning, Semiotic.

\footnotetext{
1 Zonguldak Bülent Ecevit Üniversitesi, Fen-Edebiyat Fakültesi, Sosyoloji Bölümü, Türkiye. E-mail: hsankir@gmail.com
} 
Sanat alanındaki tüm üretimler kültürel bir nitelik taşır ve içerisinde yer aldığı sosyal alanın karakteristiklerini yansıtırlar. Nesnelerin kendi başına anlamları yoktur ve sanat nesneleri de dahil her türlü nesne anlamını toplumsal inşa süreciyle kazanır. Bu bakımdan sanat eserinin anlamı sembolik ve kavramsaldır. Bu çalışmanın amacı sıradan nesnelerin sanatçılar tarafından sanat eserine nasıl ve hangi koşullarda dönüştürüldüğünün ortaya konmasıdır. Nesnelerin sanatsal dönüşümü sürecinde hangi sosyal mekanizmaların yer aldığı ve bu mekanizmaların inşası ve işleyişinde sosyal mekânın ve sanatçının rolünün ne olduğunun belirlenmesine yöneliktir. Bu amaçla çalışma iki kısma ayrıımışır. Birinci kısımda sanat alanında bir nesnenin sosyal bağlamının nasıl inşa edildiği ve bu bağlama göre nesnenin ve mekânın nasıl sanatsal bir anlam kazandığı göstergebilim yaklaşımı üzerinden ortaya konulmuştur. İkinci kısımda ise sanat tarihinden seçilen örneklerle sosyal bağlamın inşası ve sanatçının rolü üzerinden sıradan bir nesnenin sanatsal dönüşümüne yönelik bir yaklaşım ortaya konulmuştur. Bu kısımda sıradan nesne olarak "yatak" seçilmiş ve Tracy Emin' in "My Bed" (benim yatağım) isimli çalışması üzerinden yatağın sanat eserine dönüşüm sürecine yönelik bir tartışma gerçekleştirilmiştir. Çalışmanın sonucunda sıradan nesnelerin kendilerine özgü kültürel mekânlarının olduğu ve bu mekânların nesnelere yönelik anlamın ortaya çıkmasını sağlayan sosyal bağlamın inşasında etkin bir role sahip olduğu anlaşımıştır. Sanatsal bir hedefe yönelmiş olan sanatçının eylemselliği aracılığıyla sıradan bir nesnenin kültürel mekânı dışına çıkartılması ve işlevlerinden soyutlanması gibi süreçler sonucunda sosyal bağlamının ve buna bağlı olarak anlamının değiştirilmesinin mümkün olduğu belirlenmiştir. Bu süreç sonrasında nesnenin göstergeye dönüşerek anlamının genişlemesiyle birlikte sanat yapıtı olarak değerlendirilmesinin imkanlı hale geldiği görülmüştür.

Anahtar Kelimeler: Sanat nesnesi, Sosyal bağlam, Sanatsal etiketleme, Anlam inşası, Gösterge sistemi.

\section{Giriş}

Sanat yapıtı, kendisi olarak sunulanın yani görünenin ötesinde sembolik ifadeler aracılığıyla özel anlamlar taşıyan düşünceye özgü kavramsal bir üründür. Sanat yapıtları duygu ve düşüncelerin gerçekliğe dönüşmüş halidir. Bu bakımdan sanat yapıtları içerisinde üretildiği zaman diliminin düşünme biçimlerini içerir. Diğer bir ifadeyle sanat yapıtı içerisinde yer aldığı sosyal koşullardan bağımsız olmayıp, tarihsel ve kültürel bir bakış açısıyla değerlendirilmektedir. Sanat yapıtının içerisinde yer aldığı kültürel ortam, yapıtın üretim tekniği, taşıdığı semboller ve sosyal alanda sanat olarak algılanması gibi pek çok süreç üzerinde etkili olmaktadır. Gündelik yaşamdaki sıradan bir objenin sanat olarak değerlendirilmesi o nesnenin sahip olduğu özsel niteliklerden dolayı değil ona atfedilen anlamlardan dolayı mümkün olabilmektedir.

Bir yapıt ancak kolektif bir kabul sonrasında sanat yapıtı olarak değerlendirilebilir. Bu nedenle sanat yapıtlarının anlamı sabit değildir ve içerisinde üretildiği zamansal ve mekânsal uzama göre farklılaşmaktadır. Bir nesne, sanat yapıtı olarak ortaya konduğu andan itibaren estetik dışındaki tüm işlevlerinden soyutlanmakta ve kendisine tıpatıp benzeyenler de dahil tüm benzerlerinden farklılaşmaktadır. Aksi durumda tüm benzerlerinin de sanat olarak görülmesi gerekir.

Sanat alanında birbirinden farklı türde ve tarzda pek çok yapıt bulunmaktadır. Bu nedenle sanat alanında yer alan tüm yapıtları kapsayacak genel geçer bir sanat anlayışı ortaya koymak mümkün görünmemektedir. Bir nesnenin sanat olarak anlamlandırılması zamana ve mekâna bağlı olarak ancak uygun koşullar altında gerçekleşebilmektedir. Fakat söz konusu bu uygun koşullar sabit ya da verili değildir. 
Sanat eserinin anlamını tarihsel bir inşa sürecinde nasıl edindiğini ortaya koymak sanat alanında yer alan fakat gündelik yaşamda benzerlerine oldukça sık rastladığımız objelerin anlamlandırılmasına yönelik düşünsel bir alt yapı sunmaktadır. Bu düşünsel alt yapı gündelik yaşamda sıkça kullandığımız sıradan bir nesne ile müzede sergilenen tıpatıp benzeri arasındaki farkı anlamamıza rehberlik etmektedir. Bu bakımdan çalışma, sanat alanını içerisinde yer alan mekanizmaların işleyişiyle birlikte kavramamızı ve sanat eserinin kavramsal alt yapısını anlamamızı sağlaması açııından önemlidir.

Çalışma, sanat eserinin kavramsal ve kuramsal alt yapısını ortaya koymayı hedeflemiştir. Bu amaçla sanat nesnesinin içerisinde yer aldığı sosyal bağlamının inşa sürecine yönelik bir çözümleme gerçekleştirilmiştir. Böylece, göstergebilimsel yaklaşımın temel kavramları üzerinden gerçekleştirilen bir tartışmayla sıradan nesnelerin sanatsal nesnelere dönüşme sürecinde anlamlarının inşası için gerekli olan uygun bağlamların nasıl üretildiğinin ortaya konulması hedeflenmiştir.

İşlevlerinden soyutlanan nesne göstergeye dönüşmektedir. Bu şekilde kendisi dışındaki başka anlamların taşıyıcısı durumuna geçmektedir. Gösterge bilimsel yaklaşıma göre tüm nesneler kendileri dışındaki başka şeylere atıfta bulunan göstergelere dönüşme potansiyeline sahiptirler. Gösterge sisteminde yer alan süreçler kolektif kullanım yoluyla zaman içerisinde inşa edilirler.

Bir nesnenin sanat olarak kabul görmesini sağlayan gösterge sistemi genel geçer gerçeklikler üzerinden değil toplumsal bir örgütlenme yaklaşımının gündelik pratiklerinden yola çıkılarak tarihsel bir süreçte inşa edilmektedir. Bu semboller (gösterge) sistemi nesnenin, mekânın vb. anlamını tesis etmektedir. İnşa edilmiş gösterge sistemi bize karşılaştığımız uyarıcıyı nasıl anlamlandırmamız gerektiğine yönelik kılavuzluk yapacak ön bilgiyi sağlamaktadır. Örneğin bir modern sanatlar müzesinde karşılaşılan ve sergilenmekte olan tüm nesneler bu gösterge sistemi üzerinden değerlendirildiğinde sanat yapıtı olarak algılanmaları mümkün olmaktadır.

Bu tarz bir sosyal mekanizma aracılığı ile bir nesnenin sanat alanına dahil edilmesinin imkanı ortaya çıkmaktadır. Sıradan nesneler, kültürel mekânları dışına çıkartılarak örneğin müzede sergilenerek sanat eseri olarak algılanması olanaklı bir hale gelmektedir. Böylesi bir süreçte nesne kendisinde doğal olarak var olmayan özelliklere ve anlamlara sahip olmaktadır. Andy Warhol, Marcel Duchamp gibi sanatçılar yirminci yüzyııın başlarında bahsedilen bu sosyal anlamlandırma mekanizması aracılığıyla kar küreği, bisiklet tekeri, pisuar gibi hazır yapım sıradan nesneleri alarak sanat alanlarında aktarmış ve birer sanat eseri olarak sergilemişlerdir.

Tracy Emin benzer bir yöntemi kullanarak sıradan bir nesne olan kendi yatağını müzede sergilemiş ve sanat alanına dahil etmiştir. Bu yatağı diğer tüm benzerlerinden ayıran farklı bir bağlama yerleştirilerek göstergeye dönüştürülmesi ve bir sanat yapıtı olarak algılanmasını sağlayacak alt yapının yeniden inşa edilmiş olmasıdır. Böylece yatak, farklılaşarak kavramsal bir süreçte anlam kazanmış ve sanat nesnesine dönüşmüş olmaktadır. Bunu mümkün kılan sanatçının eylemselliğidir. Tracy Emin yatağın gündelik yaşamdaki uzamının devamı olmayan yeni bir uzam yaratarak onu bir sanat yapıtına dönüştürmüş ve belirli bir kavramsal sürecin (düşüncenin) ve sanatsal eylemin nesnesi haline getirerek biricikleştirmiştir.

\section{Kavramsal Bir Üretim Olarak Sanat Yapıtı ve Sosyal Bağlamı}

Tarihsel süreç üzerinden sanat alanına bakıldığında sanatın kendine özgü bir hafızası olduğu görülür. Bu hafıza içerisinde insan bilincinin ve toplumsal süreçlerin, kültürlerin değişimini takip etmek mümkündür. Sanat alanı, bir ucu uzak geçmişte diğer ucu günümüzde ve hatta yakın gelecekte olan neredeyse insanlık ile yaşıt bir süreci içermektedir. Sanat, böylesi bir süreç içerisinde her dönemin ve kültürün kendine özgü yerel ve evrensel değerler bütününü görmemize olanak sağlar. Bunu olanaklı hale getiren ise değişimin 
kendisidir. Her şey değişime tabidir ve sanat aracilığıyla bu değişimi takip etmek mümkündür. Bu bakımdan sanatın bizi bize gösteren bir ayna olduğu söylenebilir.

Geleneksel sanat eseri, biçimsel uyum, zanaat ve teknikte ustalık, düzen ile karmaşa arsındaki dengeli ilişki gibi bir dizi temel ölçüte sahip bir anlayışa sahiptir (Saehrendt ve Kittl, 2014, s. 21). Geleneksel sanat yaklaşımından farklı olarak modern sanat, stil, konu, malzeme, sergileme gibi alanlarda sınırlamanın olmadığı bir anlayışı işaret etmektedir. Modern sanat, gelenekselci yaklaşımın aksine nesnelerin oldukları gibi gösterilmesi yaklaşımına karşı çıkmışır. Kişisel deneyimleri öne çıkartan modern sanat açık uçlu bir anlayışa sahiptir. Modern sanat geleneksel olarak kabul gören "sanat yapıtı" anlayışını eleştirerek bu anlayışın aksine gündelik yaşama ait pek çok sıradan nesnenin uygun koşulların oluşturulmasıyla sanat yapıtı olarak kabul görülmesini olanaklı hale getirmiştir.

\section{Sanat Yapıtı}

Doğal bir şekilde yaşamını devam ettirme sürecinde sistematik olarak sanat ürünleri oluşturmak ve bunlara değer atfedip belirli biçimlerde bu yapıtları estetik haz için kullanılır bir duruma yerleştirmek diğer canlılarda görülmeyen yalnızca insan türüne özgü bir davranış biçimi olarak karşımıza çıkmaktadır (Atasoy, 2013, s. 11).

Sanat yapıtı, kavramsal olarak inşa edilmiş bir dizi duygu ve düşünceyi sembolik olarak aktaran ve üretiminde belirli bir tarzda yetenek, beceri ve bilgi gerektiren kültürel bir üründür. Sanatsal üretim, insana ve onun tarafından üretilmiş olan her şeye atıfta bulunabilen, göstergeye dönüşebilen, duygu ve düşüncelerin görünür hale getirilmesi sürecidir.

Duchamp'a göre, sanat eserinin yaratım sürecinin sonu sanatçının eylemi tamamlaması değildir. İzleyici eser ile gerçekleştirdiği etkileşimle kendince yapıtın içsel niteliklerine ulaşır ve böylece eserin dış dünya ile bağlantısını sağlar. Bu süreçte sanatçısı gibi izleyicisi de yaratma edimine katkıda bulunmuş olur (Kuspit, 2006, s. 34). Bu sürecin mümkün olmasını sağlayan ise sanat yapıtının kavramsal bir ürün olmasıdır.

Heidegger'e göre, sanat eseri yapılmış bir nesnedir, fakat eser salt nesneden hariç başka şeyler de söyler. Eser simgedir ve yapılmış bir nesne (sanat eseri) bizi eserde var olan başka şeylerle bir araya getirmektedir. Sanatçının eseri, eserin de sanatçıyı yarattı̆̆ını belirtir (Heidegger, 2007, s. 10).

Heinich'e göre, sanat yapıtı kendi iç özelliklerine (plastik, müzikal vb.) sahiptir ve bunlar bireyler üzerinde yarattığı etkiyle sosyal yaşama hareket kazandırırlar. Heyecanları etkileyerek duygulandırır, coşturur ve iz bırakırlar. Bilgi kategorilerini etkileyerek zihinsel kesitler oluştururlar. Değerler sistemini etkilerler ve yeni değerlerin üretilmesine aracılık ederler. Algılama sınırlarını etkileyerek duyumsal deneyimleri, algısal çerçeveleri ve bunları entegre eden değerlendirme kategorilerini programlarlar (Heinich, 2013, s. 125). Kısacası sanat yapıtları içerisinde yer aldığı gündelik yaşamın dinamiklerini harekete geçiren, yenileyen, geliştiren, üreten sosyal alana özgü gerçekliklerdir ve bu haliyle sosyal yapının üretimi ve yeniden üretimini sağlayan sosyal sistemin bir parçasını oluştururlar.

Benjamin'e göre, sanat yapıtı içerisinde yer aldığı, üretildiği koşullardan bağımsız değildir. Bu nedenle sanat yapıtı tarihsel bir özümleme ile anlaşılabilir. Bir taraftan toplumsal diğer yandan teknolojik değişim ve dönüşümler sanat yapıtının döneme göre değişen işlevini birbirine bağlar (aktaran Lenoir, 2004, s. 106). Bu bakımdan her dönemin kendine özgü sanat yaklaşımı söz konusudur. Wölflin'e göre, her şey her zaman mümkün değildir. Başka bir deyişle; kimi sanat yapıtlarının sanat tarihinin bazı dönemlerinde sanat eseri olarak yer almaları mümkün değildir(aktaran Danto, 2012, s. 64). Örneğin, Manzoni'nin 1961 yılında ürettiği ve içerisinde sanatçının dışkısının yer aldığı ve her biri 30 gram ağırlığında 90 adet teneke kutudan oluşan eserinin modern öncesi dönemde sanat eseri olarak kabul görmesi mümkün değildir. 
Becker, sanat eserinin kendisinin olmadığını bir eserin ortaya çıktığı ya da çıkartıldığı, okunduğu ya da gözlemlendiği durumlar olduğunu ileri sürer. Bu durumlar ise belirli bir uzam ya da zamanın özelliklerini taşır. Becker, bu süreci "sanat eserinin kesin belirsizliği" ilkesi olarak kavramsallaştırır. Ona göre, bir sanat eseri anacak müşterek bir tanımlama eylemi ile sanat eseri olarak nitelendirilebilir ve bu nedenle de sürekli olarak değişime tabidir. Esquenazi ise, sanat eserini değiştirilemez nesne olarak değil bilakis nesnenin yahut eserin konumunun çok kereler değiştiği bir sosyal süreç olarak görür (aktaran Danko, 2017, s. 139).

Cohen, Marcel Duchamp" ın "çeşme" isimli eserinin "pisuar" değil "pisuarı sergileme" eylemi olduğunu ileri sürer. Eğer sanat yapıtı kastedildiği gibi bu eylem ise üzerinde konuşulacak parlak yüzeyleri yoktur. Yani bu yapıtın, benzeri herhangi bir pisuarda olmayan özelliklerinin olduğu kesindir. Bir nesne sanat yapıtı olarak kabul edildiği andan itibaren ona tıpa tıp benzeyen diğerlerinden tamamen farklılaşır. Artık nesne sıradanlığından kurtularak ve sembolik anlamlara ve estetik bir bakış açısına kavuşmuştur. Bu nedenle de kendisinin bire bir kopyası olandan farklılaşmışır. Aksi halde tüm pisuarlara sanat eseri muamelesi yapılması gerekir (Danto, 2012, s. 115).

Bir nesnenin sanat eserine dönüşebilmesi için bazı kriterler söz konusudur. Heinich' e göre, sanat yaptı, sanatçının yarattığı bir objedir ve bir şey olarak (obje) değil de sanat yapıtı olarak kabul görmesi için estetik dışında bütün işlevlerinden (yarar, dinsel tapınma, hatırlatma, erotik işlev vb.) arınmış olması, imza ya da atıf aracılığı ile bir sanatçıya bağlanmış olması ve tekilleşmiş olması yani eşsiz kılınmış olması gerekir (Heinich, 2013, s. 115).

Bir gereksinime yönelik üretimler o gereksinimin karşılanması sürecinde tüketilirler. Sanat eseri bu bakımdan gereksinimleri karşılayan ve alımlayıcısı tarafından tüketilen yapıtlar değillerdir. Diğer bir söyleyişle ortaya konma amacı doğrudan bir tüketime konu olmak üzere değildir. Ardent'e göre, insana özgü becerilere bir kalıcılık kazandıran nesneler arasında tam anlamıyla bir yararı olmayan, biricik oldukları için değiş tokuş edilemeyen ve fiyatları yalnızca keyfi olarak belirlenebilenler yani "sanat yapıtları" vardır. İnsanların bu nesnelerle yani sanat yapıtlarıyla ilişkisi kesinlikle onlardan yararlanma üzerine kurulmamışır. Aksine sanat yapıtının sıradan kullanım bağlamına giren nesnelerden özenle ayrılması gerekir. Hatta olabildiğince ilgisiz olduğu günlük gereksinimlerden ve zorunluluklardan ayrılması gerekir (aktaran Lenoir, 2004, s. 115). İşlevlerinden soyutlanan nesneler göstergeye dönüşerek başka anlamların taşıyıcıları olma imkânı elde etmiş olurlar. Bu özelliklere sahip hemen her türlü nesne sanat yapıtı olabilme potansiyelini beraberinde taşımaktadır.

Herhangi bir objenin, eylemsel sürecin ya da pratiğin sanat olarak değerlendirilmesi objenin, eylemsel sürecin ya da pratiğin doğal olarak sahip olduğu herhangi özsel bir niteliğinden ötürü değil o objeye, eyleme ya da pratiğe sanat yapıtı olduğuna yönelik bir anlayış, kabulün varlı̆̆ı ile oluşmaktadır. Bu durumda sanat yapıtının anlamı sosyal alanın karakteristiklerine paralel olarak yani içerisinde yer aldığı toplumsal yapının, kültürün ve zaman diliminin karakteristik özelliklerini yansıtacak bir şekilde inşa edilmektedirler. Bu bakış açısından değerlendirildiğinde doğru koşullar bir araya getirildiği takdirde hemen her türlü nesnenin sanat eseri niteliği kazanması mümkündür. Sıradan nesneleri sanat yapan şey bu şeylerin kendisinde olan özellikler değil bu nesnelere atfedilen anlamlardır. Sıradan bir nesne göstergeye dönüştüğü andan itibaren sanat alanına dahil olabilme imkânı ortaya çıkmaktadır.

Göstergebilimsel yaklaşıma göre, tüm nesneler kendilerinden başka bir şeye atıfta bulunan göstergelere dönüşme potansiyeline sahiptirler. Bir nesne başka bir şeyi işaret eden gösterge yani başka bir toplumsal anlamın taşıyıcısı olabilir. Örneğin, değerli madenden üretilen bir yüzük olan alyans, evliliği, aşkı, sadakati aile bağlarını ve cinsiyet rollerini gösteren tipik bir sembolik göstergedir. Gösterge, doğası bakımından kaçınılmaz olarak keyfidir ve belirli bir topluluğun üyeleri tarafından kolektif kullanım yoluyla zaman içerisinde inşa edilirler (Woodward, 2016, s. 82-89). Örneğin, bir çatal ya da pipo gündelik ihtiyaçlar için 
kullanıldığı sürece bir sanat eseri değildir. Çatal ya da pipo olarak varlık alanından yani bağlamından ayrılmadıkça sanat alanına dahil olamazlar. Ancak bağlamı değiştiği takdirde göstergeye dönüşerek yeni anlamlara açık bir hale gelebilir ve bu durumda sanat yapıtı olabilme potansiyelini edinmiş olurlar. Bu durum ise bir kavramsal inşa sürecine işaret etmektedir.

Goodman'a göre, bir nesne belirli an ve durumlarda bir simgeye dönüşebildiği gibi belirli an ve durumlarda sanat yapıtı olarak kabul görebilir. Diğer bir söyleyişle bir nesne belirli bir biçimde bir simgeye dönüştüğü için ve dönüştüğü sürece sanat yapıtı olarak değerlendirilir. Bir taş yolun üzerinde öylece durduğu sürece sanat yapıtı olarak kabul görmez fakat bir sanat müzesinde sergilenmeye başladığında sanat eserine dönüşür. Öte yandan Rembrandt'ın bir tablosu soğuk gelmesini engellemek amacıyla kırık bir camı onarmak için kullanıldığı sürece sanat yapıtı olarak işlev görmeyi yitirir (aktaran Lenoir, 2004, s. 141).

Sıradan bir obje, semboller sistemine dahil olup yeni anlamlarla donatıldığında yani bir göstergeye dönüştüğünde sanat yapıtına dönüşmektedir. Bir nesne göstergeye dönüşmeden önce ancak kendisidir ve belirli işlevlere sahiptir. Örneğin bir sandalye işlevi doğrultusunda kullanılsa, üzerine oturulsa, çıkılsa ya da bunların hiç biri yapılmasa da sandalye olarak kalmaya devam eder. Fakat göstergeleşerek bir sanat yapıtına dönüşen sandalye artık üzerine oturulan diğerleriyle aynı değildir. Bu özelliğini yani diğer sandalyelerle benzeştiği tüm özellikleri yitirerek yeni bir anlam kazanır. $O$ artık semboller dünyasında yeni anlamlarla donatılmış ve bir sanat yapıtına dönüşmüş olur. Bu haliyle sandalye, üzerine oturmak için gerekli fiziki ve mekanik koşulları halen taşısa bile oturmak için değerlendirilen nesneler dünyasına ait değildir. Sandalyenin bağlamı artık değiştiği için anlamı ve bu nedenle de işlevi değişmiş olacaktır.

\section{Sanat Yapıtının Sosyal Bağlamı}

Sosyal sınıflandırmalar gündelik yaşamın temelini oluşturur ve asli kültürel pratikler olarak bireylerin bütünleşmesini sağlarlar. Toplum içerisinde bireyler sınıflandırma yaparken aynı zamanda kültürel değerler atfederler. Birbirleriyle ilişkili fakat bariz ayrımlara sahip şeylerin sınırları sınıflandırmalar aracılığıyla çizilmektedir. Saussure'a göre, bir şey ancak farklı olduğu diğer şeylerle yapısal ilişki içerisinde anlaşılabilir. Anlamın olduğu yerde yapı vardır. Farklı nesne kategorileri olduğunu anlar ve bunlara kullanımlarına göre farkı roller biçeriz. Bir nesneyi diğerlerinden farkı sayesinde bilebiliriz. Farkı yaratan nesnenin bağlamıdır. Örneğin farklı ayakkabılar olduğunu biliriz ve spor, dans, yürüyüş ve tören için farklı ayakkabıları tercih ederiz. Bu tercih, kullanım alanları yani bağlamları doğrultusunda ortaya çıkar ve aynı bağlam üzerinden rolleri ve değeri inşa edilir (aktaran, Woodward, 2016, s. 89).

Sınıflandırmalar yoluyla soyut sınırlar inşa edilmekte ve herhangi bir olgu, nesne, eylem ya da pratik bu inşa edilmiş sınırların içerisinde olma ya da dışında kalma durumuna yani konumuna göre değerlendirilmekte ve anlamlandırımaktadır. Örneğin, bir sanat yapıtı farkını sanat yapıtı olmayana göre konumuyla ortaya koymaktadır. Bu sınıflandırmalar sosyal olarak inşa edilen tüm norm değerler ve koşullardan oluşmaktadır. Herhangi bir olgu, nesne, eylem ya da pratiği çevreleyerek şekillendiren bu değerler ve koşullar sınıflandırmalar aracılığı ile sosyal sınırları yani bağlamı ortaya çıkartmaktadır.

Williams'a göre, sanat ile sanat olmayan arasındaki ayrım, tarihsel bir süreç ve sosyal alanın örgütlü yapısı içerisindeki pratikler çerçevesinde ortaya çıkan toplumsal formlara dayanır. Bu nedenle sanat ve sanat olmayan arasındaki ayrım, evrensel, genel geçer gerçeklikler şeklinde değil toplumsal bir örgütlenme türünün eylemsel pratiklerinden oluşan inşa edilmiş gerçekliklerdir. Güncel bir ürünün sanat olarak kabul edilmesini mümkün kılan toplumsal simge sistemleri tarihsel bir süreç içerisinde inşa edilmektedir. Bu simgelerin (göstergelerin) en temel hali fırsatlara ve mekâna/alana ilişkin olanıdır. Örneğin bir sanat galerisi, içerisinde yer alan yapıtların sanat eseri olarak algılanması için tasarlanmış ve bu konuda uzmanlaşmış bir mekân/alandır (Williams, 1993, s. 129). 
Barnard'a göre, toplumsal alanda yer alan ayrım ve tanımlama sistemleri farklı toplumsal grupların değer ve inançlarını ortaya koyan gösterge sistemleri olarak rol oynar. Dahili ve harici gösterge sistemleri söz konusudur. Genel olarak gösterge sistemleri sanat alanının sınılarını belirleyerek nelerin sanat olup olmadığını tanımlar. Dahili gösterge sistemleri, belirli sanat ya da tasarım biçimlerinin yöntem ve geleneklerini işaret eder. Harici gösterge sistemleri ise, sanat ya da tasarım olarak kabul edilebilecek şeylerin bulunabilecekleri yerlere, durumlara veya belirli bir zaman ve yerde sanatın varlığına işaret eder. Bunlar, insanın belirli bir zaman ve mekânda geçirebileceği deneyimlerin yapısını gösterir (Barnard, 2002, s. 175-76).

Levi-Strauss, "Yaban düşünce" isimli çalışmasında sosyal alanda yer alan tüm öğelerin anlamlarının taşıdıkları özsel özelliklere göre değil bulundukları konumlara göre belirlendiğini ileri sürer. Ona göre, öğelerin anlamı bir yandan tarihsel süreç ve kültürel bağlam diğer yandan içerisinde yer aldıkları dizgenin sonucunda ortaya çıkmaktadır. Bir diğer söyleyişle nesnelerin anlamları bu kültürel kodlar ve kurallar üzerinden belirli bağlamlara göre oluşturulmaktadır. Nesneler ancak bu bağlamlara göre anlamlandırılabilirler. Bu nedenle nesnelerin kendine has kültürel mekânları söz konusudur (Levi-Strauss, 1994, s. 80-81).

Sanat yapıtının anlamı sosyal inşa sürecine tabidir. Sosyal anlam ise sosyal bağlama göre oluşmaktadır. Sosyal bağlam kültürel, mekânsal ve zamansal uzamlara göre ortaya çıkmaktadır. Bir nesnenin kültürel mekânının değişmesi anlamı üzerinde farklılık yaratmaktadır. Bir nesnenin kültürel mekânı, sosyal alandakilerin o nesnenin bulunduğu yere özgü olduğuna yönelik kolektif kabulüyle ortaya çıkmaktadır. Kültürel mekânın değişmesi, bağlamın değişmesi ve dolayısıyla anlamının da değişmesine neden olmaktadır. Kültürel mekânı (bağlamı) dışına çıkartılan nesneler kendileri dışında başka anlamları yansıtan taşıyıcılara (göstergelere) dönüşürler. Sanat alanında nesnelerin kültürel mekânları (bağlamları) dışında kullanılarak göstergeleşmeleri ve yeni anlamlar yüklenmeleri bu tür bir sistem aracılığıla mümkün olmaktadır. Nesneler kültürel mekânları ve dolayısıyla bağlamları dışında kullanıldıklarında sembolik bir güce sahip olmaktadırlar.

Sistemli kültürel normlar ve anlam kodları nesnelerin anlamını genişletip şekillendirmekte ve onları bir bağlama oturtmaktadırlar. Nesnelerin anlamları bu bağlamlar içerisinde oluşturmaktadır (Woodward, 2016, s. 92). Bu açıdan bakıldığında her türlü nesnenin öncelikle kendine özgü temel işlev-kullanım amacı doğrultusunda yer aldığı bir varlık alanı yani "kültürel mekânı" söz konudur. Bu durumda, nesnelerin bir de ait olmadıkları, bağlamları ve kültürel mekanları dışında kullanıldıkları bir alan söz konusudur. Bu alan nesneye sembolik bir taşıyıcı yani gösterge olma fırsatı tanır. Böylece şeyler farklı kullanımlara açık bir konum elde eder ve anlamları akışkan bir hal alır. Bu konumdaki şeylerin gösterge olarak yüklendikleri anlamlar tamamen keyfidir. Her türlü nesne pek çok farklı anlamın, değerin taşıyıcısı olarak kullanılma olasılığına sembolik olarak sahip olur. Bu süreçte şeylere onlarda var olmayan özellikler, anlamlar atfedilmiş olur.

Şeylerin olmaması gereken yerde ve konumda bulunması yani bağlamları dışında bulunması halinde anlamlarının nasıl değiştiğine yönelik olarak Douglas'ın "sembolik kirlenme" yaklaşımı örnek verilebilir. Ona göre, "kir" benzersiz ve tek başına var olan bir olay değildir. Kabaca orada olmaması gereken olarak tanımlanabilir. Kirlenmenin olduğu yerde bir sistem vardır. Çünkü tanım gereği orada olması gerekenler ve orada bulunmaması gerekenler bir arada sistemi oluştururlar. "Kir" fikri, bizi doğrudan sembolizm alanına götürür. Örneğin, ayakkabılar kendi başına kirli değildir fakat yemek masasının üzerine konulduğunda kirli olarak kabul edilirler. Bir başka örnek, yemek kendi başına kirli kabul edilmez, fakat üstümüze dökülürse giysimizi kirletmiş olduğunu düşünürüz. Giysiyi kirleten yemektir. Nesne (yemek) artık olması gereken yerde değil kültürel mekânı, bağlamı dışında bir yerde, konumdadır (aktaran Alexander ve Seidman, 2017, s. 183). 
İş̧a edilen anlamların olduğu yerde bir sistemin varlığı söz konusudur. Sosyal alanın vazgeçilmezleri arasında olan bu sistem kültürel ve dinamiktir bir yapıdadır ve algıladığımız tüm şeylerin bir araya gelmesiyle oluşmaktadır. Sistem içerisindeki alanlara ve bağlamlara en uygun olanlar hızlıca kabul görürken diğerleri reddedilirler ya da yeni anlamların taşıyıcılarına dönüşürler. Böylece sosyal alanda şeylerle gerçekleştirilen her türlü etkileşimle anlamları genişletmek ve yenilerini üretmek mümkün olabilmektedir. İ̧̧leyen bu sistem sanat alanı için de geçerlidir. Kimi sanatçılar şeyleri, objeleri veya eylemleri kendilerine uygun bağlamlar/mekânlar dışına çıkartarak yeniden kültürel dolaşıma dahil etmişler ve çarpııı bir şekilde yeni anlamlar üretme şansı yakalamışlardır.

Barnard'a göre bir sanat galerisi ya da müzesi, içerisinde yer alanların sanat olacağına yönelik bir harici bir göstergedir. Bununla birlikte harici gösterge sistemleri doğrultusunda yaratılan beklentileri kasten karıştıran ve bu süreci sanat üretimi adına kullanan sanatçılar söz konusudur. Sanat üretim sürecinde kullanılan bu yöntem birkaç farklı yolla yapılabilir. Ilk olarak, sıradan nesneler kültürel mekânları dışında galerilerde sergilenebilir. Bu yöntem Carl Andre, Marcel Duchamp gibi sanatçılar tarafından uygulanan bir taktik olmuştur. Andre, 1976 yılında Tate galerisinde yüz yirmi adet ateş tuğlasını "Equivaent VIII" ismini verdiği bir heykel çalışması olarak sergilemiştir. íkinci olarak, geleneksel olarak sanat kabul edilen nesnelerin ya da çalışmaların sanat galerisi ya da müze gibi uzmanlaşmış yerler dışında sergilenmesidir. Genellikle kar, buz çim ya da diğer doğal malzemeleri kullanarak yaptığı çalışmaları açık arazilerde sergileyen Richerd Long ya da Andy Goldworthy'nin çalışmaları bu tür bir stratejiye örnek verilebilir. Burada sanat galerisini gösteren harici göstergeler var olmasa da yapılanlar sanat olarak kabul görmüştür. Son olarak sanatçı hem sergileme alanına hem de bu harici göstergeleri kullanarak geleneksel olarak sanat kabul edilen nesne ya da göstergelere meydan okuyan bir strateji geliştirir. 1970'li yıllarda yapılan performans sanatı gösterileri buna örnek olarak gösterilebilir (Barnard, 2002, s. 179).

Danto'ya göre herhangi bir şeyin sanat yapıtı olduğunu öğrendiğimiz andan itibaren o obje ile olan etkileşimimiz bu bilgiden kaynaklanan bir değişim yaşar ve o objeye yönelik estetik tepkilerimizde bir farklılaşma olur. Nesnelere yönelik en uygun etkileşimleri ortaya koyabilmek için nesnelerin bağlamlarını doğru okumamız ve bu bağlamları doğrultusunda anlamlandırarak tepki vermemiz gerekir. Kısaca söylemek gerekirse, sanat yapıtlarına uygun tepkiyi verebilmemiz için doğal ve sıradan şeylerle sanat yapıtlarını ayırt etmemiz gerekir. "Çeşme"yi (Fountain) sanat eseri yapan diğerleriyle yani kopyası diğer pisuarlarla olan ortak özellikleri değildir. Aksine onlarla farklılaştığı noktada sanat eserine dönüşmektedir. Fark yalnızca kavramsal olarak vardır. Yani fark nesnenin sosyal bağlamında ve buna göre ortaya çıkan anlamında vardır. Bu bağlamsal süreçler ise yapısal ve kurumsaldır. Toplumsal alanda inşa edilmişlerdir ve sosyal alanın karakteristiklerini taşımaktadırlar (Danto, 2012, s. 113-116).

Şahiner'e göre hiçbir nesnenin sanat alanı için kayıtsız şartsız gerekliliği yoktur ve bu nedenle sanatçı her türden malzemeyi, mekân tercihini ve örgütlenme modelini kullanmakta özgürdür. Ona göre, Duchamp, ilk hazır yapım materyaller (ready-made) ile ortaya koyduğu sanat çalışmaları ile "sanatçı hiçte sanat yapıtı olmayan yapıtlar üretir mi" sorusunu gündeme taşımış ve "sanat yapıtı" fikrini paranteze almıştır (Şahiner, 2015, s. 22-33).

Andy Warhol, ticari olarak satılan bir nesneyi ufak değişiklikle sanat yapıtı haline getirmiş ve sanat tarihinin tartışılan yapıtlarından olan "Brillo Kutusu”nu üretmiştir. Danto'ya göre, yapıt bu hali ile bir öze sahip değildir. Bu durum yapıtın yalnızca kendi özünde sanatsal özellik taşıyan bir niyetin belirtisi olarak var olduğunu işaret etmektedir. Bütünüyle öznel olan, nesnel olarak kendini ortaya koyamayan bu niyetin sanatsal özelliği nasıl ortaya konabilir? Danto'ya göre, eleştirmenlerin ve uzmanların oluşturduğu bir bilirkişi topluluğu tarafından sanat alanına ait olarak görülen ve sanatsal özelliklere sahip olduğu düşünülen şey sanat yapıtı olarak kabul edilir. Bu şeyler (yapıtlar) sanat dünyasına özgü kurumlar ve sanat tarihi olmaksızın sanat yapıtı kabul edilemezler. Bir "Brillo kutusu" (sıradan bir nesne) ile "Brillo Kutusu" 
(sanat yapıtı) ile oluşturulan sanat eseri arasındaki farkı yaratan belirli bir sanat kuramıdır (aktaran Lenoir, 2004, s. 150).

Georg Dickie, "kurumsal sanat kuramı" kavramını ortaya atmıştır. Buna göre sanat, belli bir toplumsal kurum (sanat dünyası) adına hareket eden bazı kişi ya da kişilerin değerlendirilmesine sunulan herhangi bir yapıntıdır. Danto' ya göre, sanatçı bir şeyi sanat olarak sergilerken bir arka plan kuramı uyandırdığını ve bunun sanatçının kafasında önceden planlanmadığını, sanatçının ve izleyicinin de bunu anlamasına olanak tanıyan toplumsal ve kültürel bir bağlamdan doğal olarak ortaya çıktığını belirtir. Bu anlayış doğrultusunda Warhol "Brillo Kutuları" ile doğru zaman ve koşulda her şeyin sanat eserine dönüşebileceğini göstermiştir (aktaran Freeland, 2001, s. 62-64).

Sonuç olarak sanat kuramı, sanat alanındaki bağlamın alt yapısını oluşturmaktadır. Bir sanat yapıtı ancak içerisinde yaratıldığı sosyal koşulların karakteristikleri doğrultusunda oluşturulan norm ve değerler bütünü çerçevesinde sanat olarak kabul görebilir. Üzerinde hemfikir olunan anlamlar bütünü yani kuram olmazsa bu tür yapıtlar sanat olarak kabul edilemezler. Sıradan bir objenin sanat yapıtı olarak anlamlandırılması sosyal, kültürel ve tarihsel bir süreci de kapsamaktadır. Bu yapıtları benzerlerinden farklılaştıran ve sanat olarak kabul görüp böyle de kalmasını sağlayan kavramsal inşa süreci ve bu süreç üzerine bir genel olarak bir uzlaşının yaratılmış olmasıdır. Kavramsal olarak her şey sanat eserine dönüşme potansiyelini taşımaktadır. Bu potansiyel nesnelerin doğalarında içkin olarak bulunmaz fakat sanatçının kuramsal ve kavramsal üretim süreciyle ortaya çıkmaktadır.

\section{Nesnenin Sanatsal Dönüşümü: Bir Sanat Yapıtı Olarak "Yatak"}

Marcel Duchamp, 1914'te kendi deyimiyle "görsel aldırmazlık" anlayışından yola çıkarak sıradan bazı objeleri sanat yapıtı olarak ele alan çalışmalar başlatmıştır. 1917 yılında Mott Works firmasının ürettiği bir pisuarı alarak R. Mutt takma ismiyle imzalamış ve çeşme ismini verdiği bu nesneyi bir sergiye göndermiştir (Lynton, 2004, s. 131). Şahiner' e göre, Duchamp, yapıtı olmayan yapıt yaklaşımı ile sanat nesnesinin sahip olunan değil, düşünsel kavramsal (sembolik) bir deneyim biçimi olarak anlaşılması gerektiğini ortaya koymuştur. Buna göre bir sanat yapıtı sanatçının üzerinde becerisini ortaya koyduğu bir nesne değil düşünsel bir yapı olarak anlaşıımalıdır (Şahiner, 2015, s. 33).

Çalışmalarında benzer bir anlayışa yer veren bir diğer sanatçı Tracy Emin dir. Tracy Emin, Duchamp' ın kendi bağlamından çıkartarak sağladığı anlam değişikliği ile oluşturduğu "Çeşme" (Fountain) isimli yapıtından seksen iki yıl sonra benzer bir yolu kullanarak kendi yatağını bir sanat nesnesi olarak sanat dünyasına dahil etmiştir. Bu eseriyle de 1999 yılında Turner Prize ödülüne aday gösterilmiştir (Başarır, 2009, s. 11).

Tracy Emin'in “My Bed” (Benim Yatağım) isimli yapıtı, dağınık bir yatak ve etrafa saçılmış izlenimi veren bavul, çorap, izmarit, şişe, ilaç kutuları, kül tablası, terlik gibi yaşanmışıı̆ı aktaran nesneler ve kişisel eşyalardan oluşmaktadır. Sanatçının bağlamını değiştirerek göstergeye dönüştürdüğü ve gündelik yaşamın sırdan nesnelerinden ve dağınık bir yataktan oluşan bu eseri 2000 yılında sanat koleksiyoneri olan Charles Saatchi tarafından 150 bin sterlin karşılığında satın alınmış ve ardından ünlü bir müzayede evi olan Christie's de açık arttırmada 2,2 milyon sterlin gibi oldukça yüksek bir fiyata alıcı bulmuştur. 




Tracy Emin, Benim Yatağım (My bed) https://fineartmultiple.com/blog/tracey-emin-my-bed/ Erişim Tarihi: 04.072018

Tracy Emin gibi "yatak" metaforunu kullanarak sanat çalışmaları gerçekleştiren başka sanatçılar da olmuştur. Bu sanatçılardan ilk akla gelenler; Sarah Lucas, Ronald Jones, Sophie Calle, Loise Bourgeois, Hanah Wilke, Nobuyoshi Araki ve Robert Rauschenberg dir.

Sarah Lucas, eski bir yatağı alarak üzerinde uzanmış bir çifte çağrışım yapacak şekilde kova ve kavun, salatalık, portakal gibi meyve ve sebzeleri yerleştirerek toplumsal cinsiyet rollerine gönderme yapan bir çalışma ortaya koymuştur. 


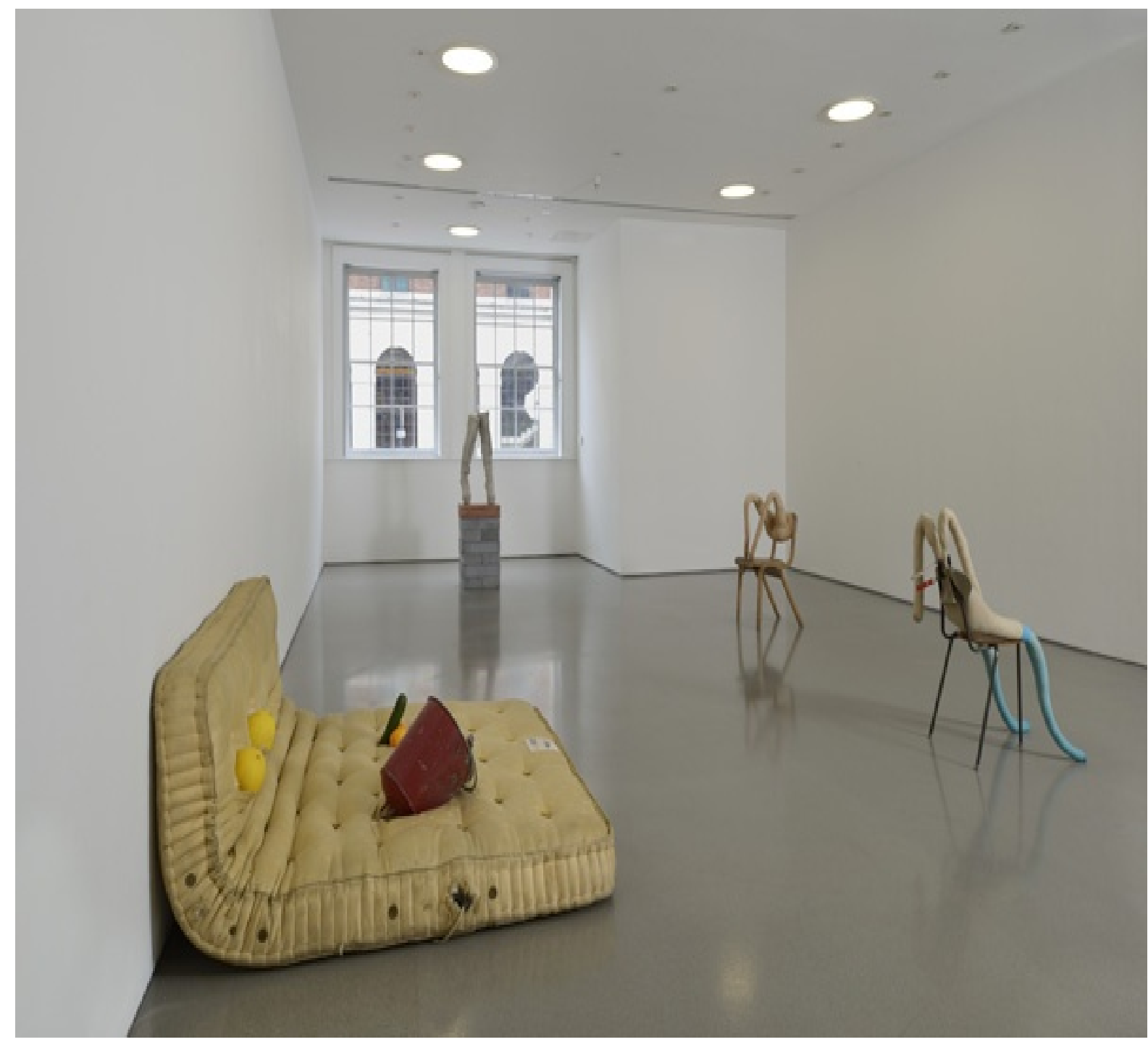

Sarah Lucas, Sıradan Şeyler (Ordinary Things)

https://www.google.com/search?q=sarah+lucas+bed\&tbm=isch\&tbo=u\&source=univ\&sa=X\&ved=2ahUKE wjvmM7Xu6PcAhVDQZoKHbteAOgQsAR6BAgFEAE\&biw=1846\&bih=896\#imgrc=Tmr3eFc6jzpgEM:\&spf=15

31738973476 Erişim Tarihi: 04.072018

Ronald Jones, kimi hazır nesnelerin (ready made) ifade edilmesi güç olan toplumsal, siyasal olayların anlatımını kolaylaştıran bir yönü olduğunu fark etmiş ve çalışmalarını bu yönde gerçekleştirmiştir. Ona göre, gündelik nesneler anlamlarını sadece kültürel ve tarihsel süreçte kendilerine özgü yaşanmışıklarının, öykülerinin ortaya konmasıyla anlamlarını dışa vurabilmektedir ve eserleri bu tarz nesneler kullanılarak gerçekleştirilen yerleştirmelerden oluşmaktadır. Örneğin 1998'de üç yatak sergilemiştir. Kullanılmış yataklar ile yatakların ardında duvara yerleştirilen ve üzerlerinde bu yatakların kimlere ait olduğunu anlamamızı sağlayan küçük etiketlerin olduğu bir çalışma gerçekleştirmiştir. Birinci yatak, Neil Armstrong'un aydan geri döndüğü gece uyuduğu yataktır. i̇kinci yatak, Jack Ruby'nin 1963'te Başkan Kenedy'yi öldüren Lee Harvey Oswald'ı vurmadan önceki gece yattığı yataktır. Sonuncusu ise, Rosenberg davası olarak bilinen ve soğuk savaş dönemi Mc Carthy Amerika'sını anlatan bir olayla ilgilidir. Amerika Birleşik Devletleri'nin ürettiği atom bombasına ait bilgileri Sovyetlere vermekle suçlanan elektrik mühendisi olan Julius Rosenberg ve karısı elektrikli sandalyede idam edilir. Bu yatak, Julius'un karısı olan Ethel Rosenberg'in 1953 yılında idam edilmesinden bir gece önce son kez uyuduğu yataktır. Böylece sanatçı Amerikan tarihinin dönüm noktalarını yapıtında bir araya getirmiştir (Heartney, 2008, s. 51). 


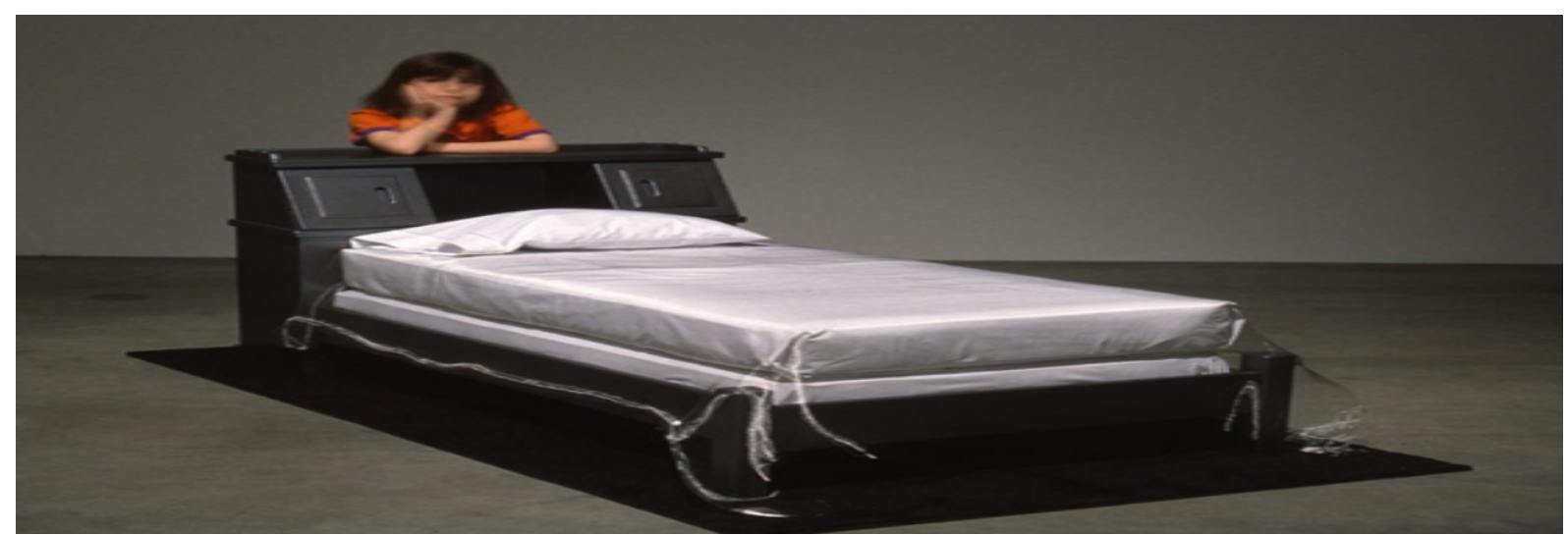

Resim I. Ronald Jones; Neil Arsmtrong' un yatağı, http://www.metropictures.com/exhibitions/ronaldjones7/selected-works?view=slider\#2 Erişim tarihi: 04.07.2018

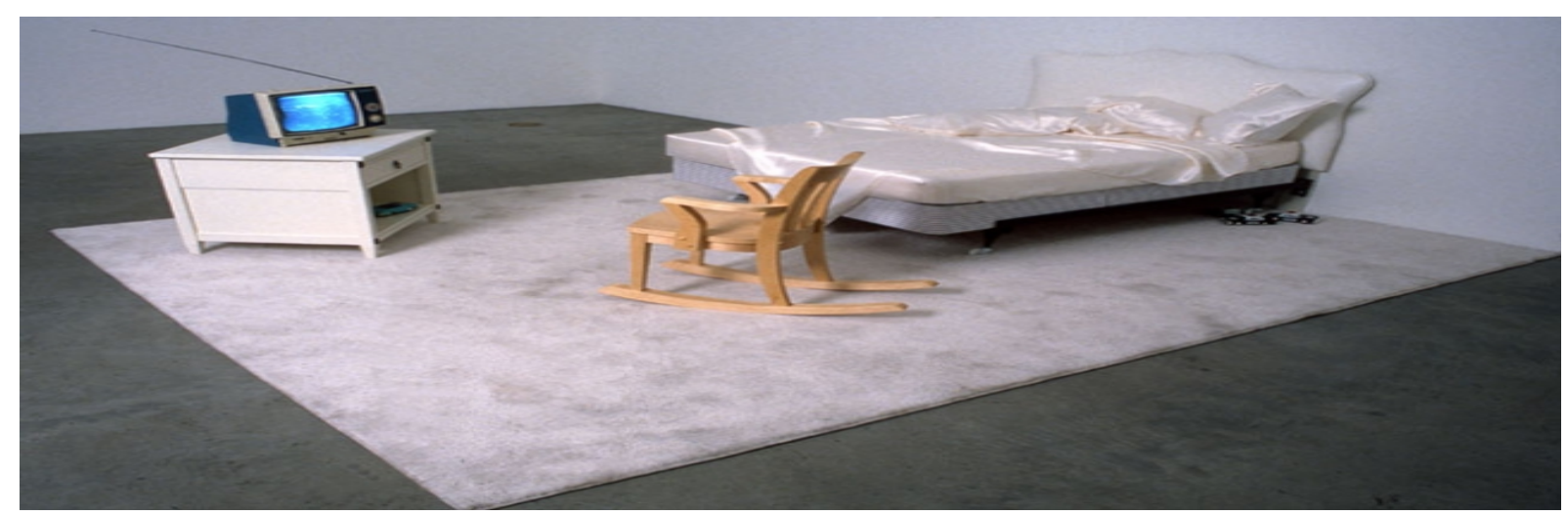

Resim II. Ronald Jones; Jack Ruby' nin yatağı, http://www.metropictures.com/exhibitions/ronaldjones7/selected-works?view=slider\#3 Erişim tarihi: 04.07.2018

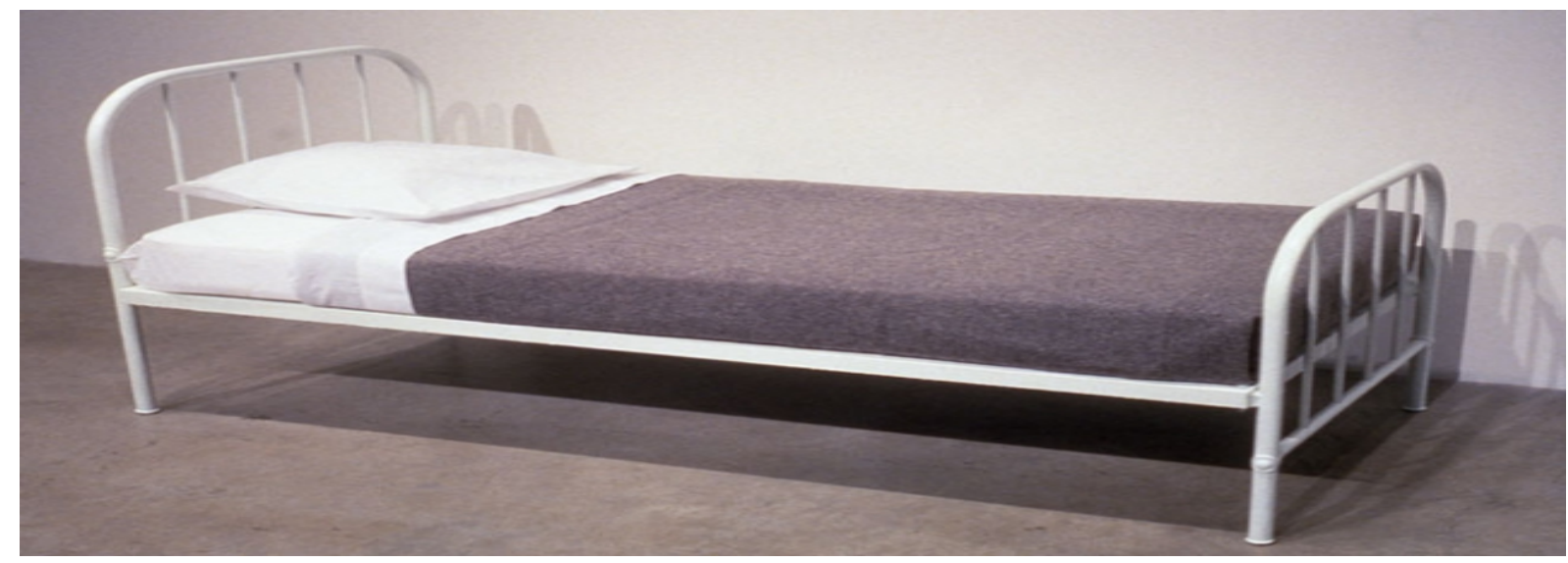

Resim III. Ronald Jones; Ethel Rosenberg' in yatağı http://www.metropictures.com/exhibitions/ronaldjones7/selected-works?view=slider Erişim tarihi: 04.07.2018

Robert Rauschenberg ise, 1955 yılında "Bed" (yatak) isimli bir çalışma gerçekleştirmiştir. Çalışmasında yatağını çarşaf takımlarıyla birlikte boyayarak onu bir tuval olarak kullanmış ve sanatsal çalışmasını bu yatak üzerinde oluşturarak böylece sergilemiştir. 


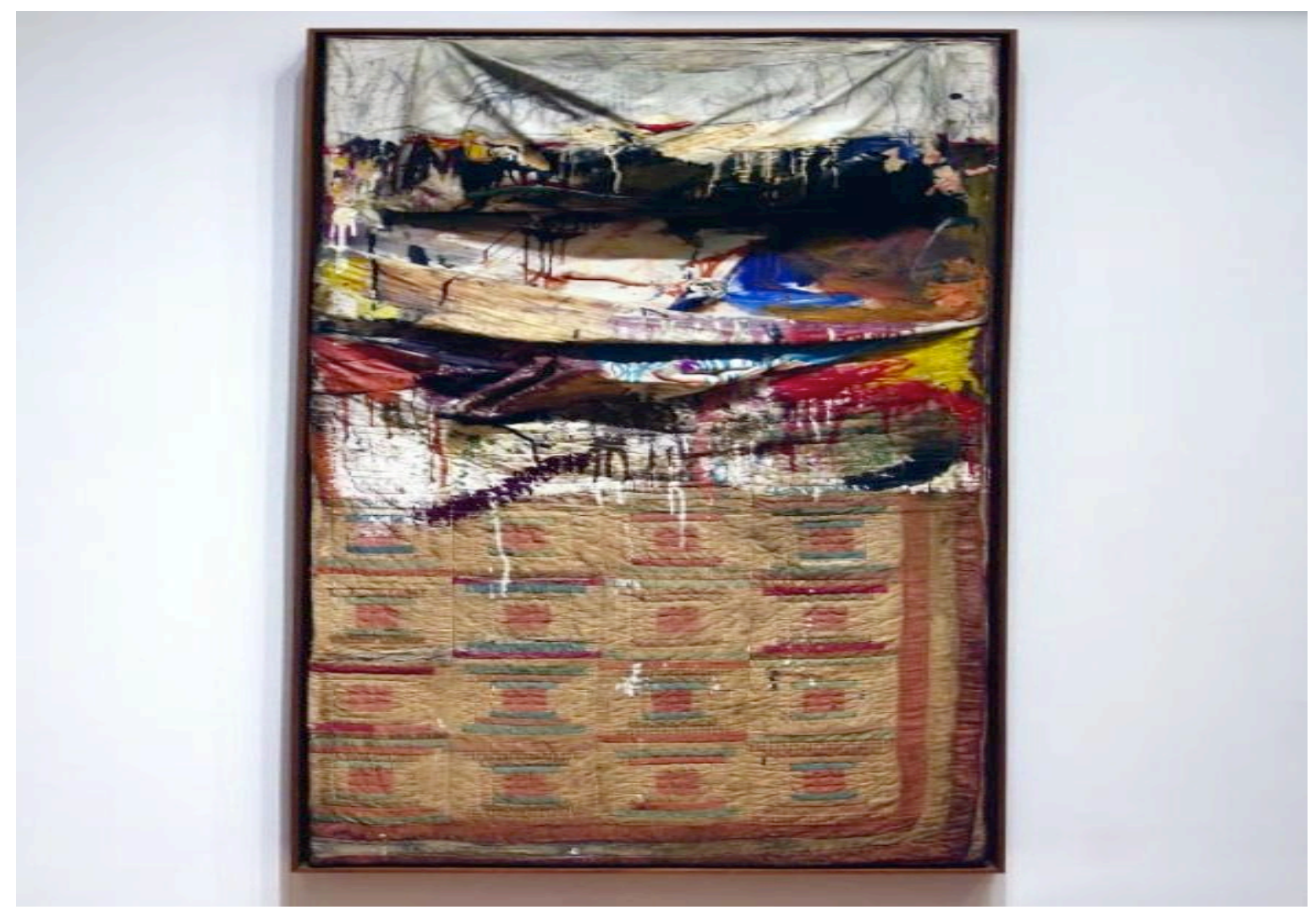

Robert Rauschenberg, "Bed" (Yatak) http://mcarte.altervista.org/robert-rauschenberg-bed-1955/ Erişim tarihi: 04.07.2018

Sanatın son yüzyıldaki hareketi incelendiğinde pek çok farklı tarz, yapıt, eylem ve sürecin sanat alanına dahil edilmiş olduğu anlaşılmaktadır. Örneklerde yer alan ve gündelik yaşamda bir ihtiyacın karşılanması amacıyla üretilmiş olan yatağın farklı sanatçıların ellerinde farklı sanatsal objelere dönüştüğü görülmektedir. Sıradan objelerin sanat alanına dahil olması ve sanat tarihindeki yerleri alarak önemli müzelerin ve galerilerin koleksiyonlarına dahil edilmeleri aynı zamanda bu yapıtlara yönelik sanat eseri olarak kabul edilip edilmeyeceklerine dair tartışmalara da bir cevap olmaktadır. Bu noktada sanat nesnesinin kendine has bir özünün bulunmadığı söylenebilir. Doğru koşullarda ve uygun bir bağlamda her nesnenin sanat olabilme imkânı var ise; bir nesneyi sanat eseri yapan şey özündeki muhteva değil ona atfedilen anlam ve temel kabuller olmaktadır. Bu anlam örüntüleri, temel kabuller ve pratikler sanat alanındaki sosyal bağlam örüntülerini oluşturmaktadır.

Gündelik yaşamın ayrılmaz parçalarından biri olan "yatak" doğal olarak bulunması gereken yerin dışına çıkartılarak bir göstergeye dönüşmesiyle birlikte yeni anlamların taşıyıcısı haline gelmektedir. Tracy Emin, kendi yatağını evinden alarak sergi salonuna getirmiş ve gündelik yaşamını yansıtacak şekilde sergileyerek onu bir sanat yapıtına dönüştürmüştür. Mekânın sergi salonu olması orada karşılaştığımız şeylerin sanat yapıtı olarak algılamamızı sağlayan bir bağlam sunmaktadır. Bu açıdan bakıldığında yatağın bir müzede ya da sanat galerisinde sergilenmesi onu harici gösterge sisteminin bir parçası yapmaktadır. Böylece sergilenen yatak bir sanat yapıtı olarak algılanmaktadır.

Bu süreçte sosyal bağlamı doğrultusunda nesnenin sanat alanına ait olduğu ve dolayısıyla sanat yapıtı olduğuna dair bir etiketleme yapılmış olmaktadır. Yatak burada tüm gündelik işlevlerinden ve üretilme amacından soyutlanmış olmaktadır. Kendisine tıpatıp benzeyen seri üretim kopyalarından da farklılaşmaktadır. Sosyal bağlamı ve sanat alanındaki etiketleme süreci onu benzersiz kılmaktadır. Sanat yapıtı olarak etiketlenmesi sürecinde, belirli bir toplumsal kurum adına hareket eden, değerler ve 
normların inşasında görev alan ve sanatçı, izleyici, koleksiyoner, eleştirmen, müze gibi pek çok kişi ve kurumdan oluşan sanat kamusu diyebileceğimiz bir alanın ürettiği değerlendirmeler etkili olmaktadır. Bu tür değerlendirmelerin toplamı aynı zamanda belirli bir sanat kuramının alt yapısını oluşturmaktadır.

Sanat alanına ait nesnelerin anlamları diğer nesnelerden farklı olarak üretilme amaçları ve işlevinden bağımsız şekilde kavramsal olarak inşa ediliyorsa bu durumda sanat nesnelerine anlam atfedebilmek için kuramsal bir sosyal sınıflamaya gereksinim duyulmaktadır. Bir nesneyi sanat eseri olarak görmeyi mümkün kılacak bir yorum, kuram ve ya yaklaşım olmadan hiçbir şey sanat eseri olarak kabul görmez. Yatağı sanat alanına dahil eden ve gerçekte sadece kendisi olarak kalmasını yani yatak olarak kalmasını engelleyerek bir sanat yapıtı olarak kabul görmesini sağlayan sanat kamusunun tarihsel süreçte ürettiği tüm kavram ve kuramlardır. Bu yatağı, diğerlerinden ayıran sanat alanının inşa ettiği anlam örüntüleridir. Tıpatıp benzeri sanat eseri olarak kabul görmezken müzede sergilenen hali sanat yapıtı olarak değerlendirilmektedir.

\section{Sanatçının Eylemselliği}

Danto, sanat kamusunun (sanat dünyası) sanatçının bir şeyi sanat eseri olarak sergilemesi sürecinde bir arka plan oluşturduğunu (sanat kuramı) belirtir. Ona göre bu kuramsal arka plan sanatçının da izleyicinin de olup biteni anlaması anlamlandırmasını sağlayan toplumsal ve kültürel bir bağlamdan ibarettir. Sanat eseri anlam ifade eden bir yapıttır. Sanatçı, alımlayıcının anlayabileceği, paylaşılan bir sanat kuramına dayanan ve sanat olarak kabul gören bir yapıt ortaya koymaktadır (aktaran Freeland, 2001, s. 63-64).

Tracy Emin'e ait olan bir yatağın sanat olarak kabul görmesi bu tarz çalışmalara yönelik kuramsal bir arka planın varlığına da işaret etmektedir. Bu kuramsal arka plan, sanatçının diğer yapıtları, sanat kamusunun müzeler, sanat koleksiyonerleri gibi diğer aktörleri, çalışmalarında benzer yaklaşımlar kullanan diğer sanatçılar, modern sanat yaklaşımı, kavramsal sanat anlayışı gibi kuramsal fakat aynı zamanda toplumsal ve kültürel bağlam ile alakalıdır. Tüm bu karmaşık sosyal sistem sanat dünyası olarak kavramsallaştııılan sosyal alanı oluşturmaktadır ve bu alanın alt yapısı Tracy Emin'e ait bir yatağın müzeler, sanat galerileri gibi aracı kurumlar üzerinden sanat alanına dahil edilmesini olanaklı kılmaktadır.

Fakat bir nesnenin müzede sergileniyor olması onun sanat olarak kabul görmesinde yeterli değildir. Onu müzeye sergilemek amacıyla yerleştiren kişi yani özne (sanatçı) bu süreçte önemli bir role sahiptir. Öznenin konumu, amacı ve eylemselliği ürettiği yapıtı sanat alanına taşıyan önemli bir parametredir. Bir kimsenin sanatçı olduğunu bilmek onun yapıtlarına bakışımızda bir farklılık yaratır. Sergilenen yatak müzeye sıradan biri tarafından getirilmiş değildir. Tarcy Emin, bu eseri kavramsal olarak üreten ve sanat kamusu diyebileceğimiz bir yapı tarafından eserleri sanat olarak değerlendirilen, takip edilen bir sanatçıdır. Tracy Emin, belirli sanatsal hedeflere yönelik olarak kavramsal bir süreç içerisinde sembolik göstergelerle donatarak düzenlediği yatağını sergilemeyi tercih etmiştir. Bu süreç sanatçının eylemselliğidir ve yatağını bir göstergeye dönüştürerek sanat alanına dahil etmiş olmaktadır.

Langer'e göre, sanat eseri ifade edici özelliğe sahiptir. Sanat yapıtı, formu aracılığıyla soyut yapıyı ve karşılıklı bağımlı bir ilişkinin sonucu olarak bütünün bir araya gelişini ifade eder. Sanatçı fiziksel biçimlerle aslında görünenden daha fazla şeyi kasteder. Böylece sanat yapıtı ifade edici form içeren bir şey olarak değil doğrudan ifadesel formun kendisi olarak görülür. Diğer bir söyleyişle somut olan sanat eseri soyut olarak görünür ve algılanır (Langer, 2012, s. 18).

Bu bakımdan değerlendirildiğinde Tracy Emin'in "My Bed" isimli eseri izleyicisiyle buluştuğu an izleyici somut bir nesne olarak yatağı değil bir yatak ile gerçekleştirilmiş sanat yapıtını ve onun aktardığı sembolik anlamları, mesajları algılamaktadır. Zira, Tracy Emin'in yapıtının biçimi, renkleri, içerdiği objeler ve bu objelerin konumları ve fiziki durumları, yatağın dağınık hali gibi tüm bu unsurlar ile ortaya konan kompozisyon öncelikle yaşanmışık, samimiyet, mahremiyet, kaygı gibi duyguların ve bunlara yönelik 
anlamların sembolik işaretlerini oluşturmaktadır. Bu işaretler gündelik yaşama dair gerçeklerin sıradanlığını ve zorunluluğunu ortaya koymaktadır. Yatağa yüklenen bu anlamlarla müzeye sergilenmek üzere yerleştirilmesi sonucunda uygun bağlam oluşturulmakta ve sanat eseri olarak algılanması süreci tamamlanmış olmaktadır.

Şahiner'e göre, sanatsal etkinlik ortaya koyduğu yapıt aracılı̆ııla anlamı görünür hale getirmektedir. Bu durum sanatın özgürlüğüdür ve sanatı yalnızca bir kopya olmaktan alıkoyar. Çünkü sanat eseri yapısı gereği içerdiği anlamın dile getirilmesine yaramayan tüm özelliklerden kendini arındırır. Böylece geriye yalnızca anlamı yansıtan gösterge kalır (Şahiner, 2015, s. 57). Bu bakımdan Tracy Emin'in yatağı kendini sıradan bir yatak yapan tüm diğer özelliklerden soyutlamış ve anlamı açığa çıkartan bir yapıta dönüşmüştür.

Sanatçı genelleme yapmaz. Sanat yapıtı somutlaşmış anlamının tekil bir sembolüdür. Yapıt bir sembol olacaksa ifadesel formu vurgulamalıdır. Sanatçı, eserin formunu tekrarlayan bir şey olarak ortaya koymaz aksine yapıt biriciktir. Yapıt, tam olarak o anda, o örnekte ve düzenlenmiş uzamda algılandığı için kendisini etkili bir biçimde gösterecek güçlü araçlara sahip olmalıdır. Yapıtı yorumlamak için değil fakat önemli duygusal kavramları ifade eden bir form olarak görebilmek için farklı biçimlerde gördüğümüz doğadan ayrılması gerekir. Sanatçı bunu içinde bulunduğu gerçek uzamla hiçbir devamlılığı olmayan zahiri bir uzam yaratarak yapar (Langer, 2012, s. 31).

Kısaca sanatçı, eserinin doğadaki ya da gündelik yaşamdaki diğer benzerlerinden ayrılması için içinde bulunduğu gerçek uzamla devamlılığı olmayan yeni bir uzam yaratarak yani yapıtın içerisinde yer aldığı bağlamı yeniden düzenleyerek ya da değiştirerek sanat nesnesinin göstergeye dönüşmesini ve yeni anlamlar üstlenmesini sağlamaktadır. Böylece herhangi bir nesne bağlamının farklılaştırılması süreciyle sanat alanına dahil olabilmekte ve benzerlerinden ayrılarak bir duygunun, düşüncenin somut ve tekil bir ifadesine dönüşmektedir. Tracy Emin, yatağın gündelik yaşamdaki uzamının devamı olmayan yeni bir uzam yaratarak yani bağlamını değiştirip bir sergi salonunda sergileyerek yatağını tüm benzerlerinden soyutlamış ve onu belirli bir fikrin biricik bir sembolüne dönüştürmüştür.

Bir yatak, mobilya mağazasında satılmak üzere sergilenen gündelik yaşamın sırdan bir nesnesi konumundadır ve değişim değeri üzerinden bir anlama sahiptir. Yatak satın alınıp eve getirildiğinde artık bir insanın özel eşyası olarak onun hikâyesinin bir parçasına dönüşmekte ve mağazadakinden daha farkı olarak sosyal bir anlama sahip olmaktadır. Benzer şeklide birinin özel eşyası olarak bir yatak sanat galerisine getirilerek amacı dışında yani uyumak, dinlenmek için değil de sanatsal bir amaçla sergilenmek maksadıyla yerleştirilip izleyicisine sunulduğunda bir sanat yapıtına dönüşme potansiyeline sahip olmaktadır. Gündelik yaşamdaki herhangi bir nesne olarak yatağın müzede sergilenmesiyle birlikte bağlamı değişmekte ve dolayısıyla anlamı da değişerek sanat yapıtı olarak değerlendirilme imkânı ortaya çıkmaktadır.

\section{Mekânın Sosyal Bağlamı}

Sanat alanındaki gösterge sistemleri sanat olarak kabul edilecek şeylerin bulunabilecekleri yerlere, durumlara ve belirli zamanlarda sanatın varlığına işaret ederler. Nesnelerin toplumun görece geneli tarafından kabul gören kendine özgü mekânları söz konusudur ve anlamları bu mekânlara özgü bir şekilde inşa edilmektedir. Bu durumda bir nesnenin anlamı inşa edilmiş ise bu anlam aynı zamanda değişken ve kültüreldir. Değişkenliği bulunduğu uzama ait sosyal sistemdeki yeri ile alakalıdır.

Bir yatağın, otelde, evde, yatakhanede, bir yolcu gemisinde, trende, hastanede ya da bir hapishanede adı, işlevi, kullanım amacı benzerdir. Uyumak, dinlenmek üzere tasarlanmışlardır bu bakımdan özsel olarak benzer nesnelerdir. Hastanedeki, yolcu gemisindeki ya da hapishanedeki yatak özsel olarak aynı olsa da 
kültürel olarak mekânları yani bağlamları değiştiği için yaşanmışlıkları, hikâyeleri ve sembolik anlamları da değişecektir. Bu bakımdan lüks bir yolcu gemisinin kamarasında yer alan yatak ile bir hapishane hücresindeki yatak özsel olarak aynı olsa bile sembolik olarak aynı şeyleri işaret etmezler. Bunun gibi bir yatak bir müzeye sergilenmek üzere yerleştirildiğinde özü değişmez fakat bu mekânda algılanışı diğer mekânlarda olduğundan farklılaşmaktadır. Aynı yatak bahsi geçen her farklı mekânda doğal olarak farkı anlamların taşıyıcısı haline gelmektedir. Buradaki farklılık özde değil atfedilen anlamda kavramsal olarak ortaya çıkmaktadır.

Mekânların bağlamları kolektif bir inşa süreci ile konvansiyonel olarak önceden tanımlanmaktadır. Örneğin, cami, kilise, havra gibi mekânlar kutsalla ilişkili kamusal alanlardır. Burada bulunan insanlar kutsal ile etkileşim içerisinde pratikler, ritüeller gerçekleştirmektedirler ve bu alanlarda bulunan nesneler kutsal ile bağlantılı olarak anlamlandırılırlar. Mekâna özgü tüm bu nesneler yalnızca kendilerinden ibaret değillerdir. Kutsalla sarmalanarak anlamları inşa edilmiş ve kendilerinde önceden bulunmayan yeni sembolik anlamlara sahip olmaktadırlar.

Örneğin, Camide; kutsalla ilişkilendirilmiş olarak konumlandırılan halılar, tespihler, kutsal kitaplar, rahleler, ahşap ya da taş süslemeler, minber, duvarlarda hatlar, duvar süslemeleri, çiniler vb. yer almaktadır. Benzer şekilde bir kilisede de bağlamına uygun olarak mumlar, oturma sıraları, kutsal kişilerin resimleri, heykelleri, haç şeklinde objeler, ayin için gerekli özel araç gereçler vb. bulunur. Tüm bu nesneler sembolik olarak belirli anlamları taşımaktadırlar ve bulundukları mekânla bu anlamda uyumludurlar. Bu uyumu bozacak nesneler genellikle o alana ait bulunmayacakları için yeni anlamların taşıyıcıları olarak görülürler.

Sanat galerileri ve müzeler sanat ve sanat olmayan ayrımına yönelik toplumsal sembol sisteminin ancak bir parçasını oluşturur. Sanat yapıtlarının müzeler, galeriler gibi uzmanlaşmış alanlar dışında kilise gibi dini mekânlar, metro, tren istasyonları, parklar ve alışveriş merkezleri gibi pek çok farklı kamusal alanlarda sergilenmesi söz konusudur. Gösterge sistemleri üzerinden sıradan bir objenin sanat alanında uzmanlaşmış alanlar aracılığı ile sanat yapıtına dönüşebildiği gibi her hangi bir kamusal alan da sanat eseri olarak kabul gören yapıtların sergilenmesi aracııığıyla sanat alanına dönüşme olanağını elde etmektedir. Her iki durumda da yani mekânın ya da objenin sanat alanına dahil olma sürecinde gösterge sistemleri devreye girerek sosyal bağlamın yeniden inşasını sağlaması ve buna bağlı olarak mekânın ya da objenin anlamının değişmesi söz konusudur.

Sanat yapıtı sergilenen yerler doğrudan sanat alnının bir parçası olmak zorunda değildir. Bu alanlar öncelikli inşa amaçları ve işlevleri dışında farklı fonksiyonları yerine getirebilmektedirler. Bu durumda bu alanların gösterge sistemi üzerinden yeni bağlamların ve dolayısıyla anlamların taşıyııısına dönüştükleri söylenebilir. Bir kilisede ya da tren istasyonunda resim heykel sergisinin açılması durumunda kilise veya istasyon (mekân) sanat yapıtlarının sergilendiği sürece gösterge sisteminde yer alan gösteren konumunda olacak ve sergilenen sanat yapıtları ise gösterilen olarak işlev görecektir. Burada bir göstergenin göstergeleşmesi söz konusudur. Sanat yapıtının sergilenmesi sürecinde devam eden bu durum sergileme sürecinin bitmesiyle de tamamlanmış olur.

Bu tür mekânlara yerleştirilen nesneler bağlamını yani sanat yapıtı anlamını kaybetmezler. Tıpkı uygun bağlamların kullanılması koşuluyla sıradan bir nesne ile sanat yapıtı olarak kabul edilecek olan nesne arasındaki farkın ortadan kalkması sürecinde olduğu gibi sanat yapıtı barındırması bakımından sıradan mekânlar ile önceden tanımlanmış sanat mekânları arasındaki sınırlarda da böylece kalkmış olur.

Boynudelik'e göre, sanat yapıtı sergilenen alanlar olarak tanımlanan sanat müzeleri ve sergi salonları gibi mekânlara yerleştirilen nesneler kolaylıkla sanat yapıtı olarak anlamlandırılmaktadır. Bir bisiklet tekeri ile bir yağlıboya resim arasında bulundukları mekânın sanat müzesi olması durumuna bağlı olarak sanat yapıtı olarak kabul görülmelerinde bir fark kalmamıştır. Bu durumda sanat yapıtı olabilme potansiyeli hemen her türlü nesne, pratik ve eylem için geçerlidir. Önceden tanımlanmış konvansiyonel mekânlarda yani sanat 
müzelerinde bulunmaları halinde nesneler sanat yapıtı olarak kabul görebiliyorsa sanat yapıtı olarak kabul edilecek nesnelerin sınırı ortadan kalkmış olmaktadır. Aynı şekilde sanat nesnelerinin bulunabileceği konvansiyonel mekânların da sınırları ortadan kalkmaktadır. Böylece müze, sanat galerisi gibi mekânlar dışında sanat eserlerinin sergilenmesi söz konusudur. Kilise, cami gibi kutsal mekânlarda, alışveriş merkezleri, parklar ya da kent meydanları veya tren istasyonları gibi kalabalık kamusal alanlarda okul, ev, boş bina, depo gibi yerlerde hatta çöl, deniz, göl gibi alanlarda sanat yapıtlarının sergilenmesi söz konusudur (aktaran Kortun, s. 30-31).

Tracy Emin'in eylemselliği yani yatağını bir sergi salonunda sergilemesi onun sanat yapıtı olarak görülmesini sağlayan etkenlerden biridir. Fakat Tracy Emin, yatağını sanat yapıtı olarak bir tren istasyonunda ya da bir kilisede sergilediğinde yatak yine sanat yapıtı olarak anlamlandırılacaktır. Bunla birlikte sergilendiği alan geçici bir süreliğine sanat yapıtına işaret eden bir göstergeye dönüşecektir. Bir yatağın doğal olarak kültürel mekânı, yatak odası, otel odası gibi uyku veya dinlenme alanlardır. Yatağın tren istasyonunda bulunması doğal olarak bu alana özgü kültürel mekânın bir parçası değildir.

Bu durumda yatağın bulunduğu mekân ile ilişkisi yeniden değerlendirilerek yeni bir anlamın taşıyıcısı olup olmadığına bakılmaktadır. Bu alanda yer alan yatak, yolculardan birinin beraberindeki bir eşya, başka bir yere taşımak amacıyla götürülen bir yük, yolculardan birinin unuttuğu bir kargo olabilir ya da evsiz bir insanın geçici barınma alanı kullanılmış ve bu kişinin mekândan ayrılmasıyla birlikte çöpe atılmak üzere bir kenara yerleştirilmiş olabilir. Bu tip örnekler çoğaltılabilir. Bu anlamlandırma süreçlerinin hiç birinde yatak, bir sanat yapıtı olarak görülmez.

Bir sanat yapıtı olarak yatağın sergilenmek üzere yerleştirilmesi bulunduğu mekânın anlamında bir farklılık yaratmaktadır. Mekânın yeni anlamı, -geçici bir süreliğe de olsa- bu alanın sanat yapıtlarının kültürel mekânı olabileceğine yönelik bir algının oluşması yönündedir. Mekânın kullanımına yönelik bu yeni yaklaşım yani mekâna yerleştirilen ve onun kültürel belleğinde daha önceden var olmayan bu yeni anlamlar mekânın işlevine, kuruluş, inşa, kullanım amacına kısaca özüne yönelik kalıcı bir değişiklik getirmemektedir. Bu açıdan Tracy Emin'in yatağı sergilendiği takdirde tren istasyonunun kabul görmüş konvansiyonel anlamında bir kayıp yaşanmaz. Yani önceden edindiği anlamların hiç birinde bir eksilme olmaz aksine bunlara bir yenisi eklenmiş olur. Böylece yapıt sergilendiği sürece mekânın bağlamı bir farklılaşmaya tabi olur ve buna bağlı olarak özü aynı kalmakla beraber anlamı genişlemektedir. Nesneleri farklı bağlamlar içerisine yerleştirerek anlamlarını genişletmek mümkün olmaktadır.

\section{Sonuç ve Tartışma}

Sosyal alanda var olan sınıflandırmalar beraberinde sınırları ortaya çıkartmaktadır. Ayrım ve tanımlama sistemleri olan sosyal sınıflandırmalar ve sınırların inşa süreci üzerinde değer ve normların yani sosyal alanın karakteristiklerinin belirleyici bir etkisi söz konusudur. Bu nedenle de sosyal alanın düzenliliklerini yansıtarak asli kültürel pratikler olarak bireylerin bütünleşmelerine katkı sağlarlar. Toplumsal alan içerisinde herhangi bir nesneyi çevreleyerek şekillendiren sistemli kültürel kodlar, değerler ve normlar sistemi yapısal bir ilişki içerisinde sosyal bağlamı ortaya çıkartmaktadır.

Sosyal alana özgü nesneler bu sınırlara göre konum almaları yani bu sınırların içerisinde ya da dışında kalmasına göre anlamlandırımaktadır. Bu işleyiş sanat alanı için de geçerlidir ve sanat alanında yer alan bir nesne ile benzeri olan sıradan bir nesne arasındaki fark bu süreçte ortaya çıkmaktadır. Bir nesnenin sanat yapıtı olarak kabul edilmesini sağlayan sosyal alanın örgütlenme anlayışının ortaya koyduğu düzenliliklerdir. Bu düzenlilikler doğrultusunda nesne göstergeye dönüşme imkânı elde etmektedir. Böylece nesnelerin gösterge olarak aktardıkları anlamların doğru bir şekilde algılanması sağlanmış olur. Bu bakımdan bir yapıtın sanat eseri olarak değerlendirilmesi o yapıtın özsel bir niteliğinden 
kaynaklanmamakta o yapıta sanat eseri olarak anlam atfetme süreci sonucunda ortaya çıkmaktadır. Bu süreç üzerinde sanat alanını oluşturan tüm bileşenlerin önemli bir rolü vardır.

Bir yapıtın sanat eseri olarak nitelendirebilmesi kolektif bir kabul süreci sonrasında mümkün olabilmektedir. Kolektif kabulü ortaya çıkartan ise sanat kamusu ya da sanat dünyası diyebileceğimiz ve sanat alanının tüm bileşenlerini içeren bir yapıdır. Sanat kamusu; sanatçı, eleştirmen, izleyici, koleksiyoner, gibi bireylerin eylemlerinden ortaya çıkan bir yapı ile sanat müzeleri, sanat galerileri gibi kurumsal yapıların bir araya gelmesinden oluşmaktadır. Sanat kamusu sanat alanındaki sosyal sınırların inşasında son derece belirleyici bir role sahiptir.

Sanat yapıtı doğrudan sosyal alanda ortaya çıkan herhangi bir gereksinimin karşılanmasına yönelik olarak üretilmiş şeyler değillerdir. Zira gereksinimlerin karşılanmasına yönelik üretilmiş nesneler bu ihtiyacın karşılanması sürecinde tüketilirler. Sanat yapıtı kavramsal, kültürel bir ürün olarak böyle bir tüketime konu olması mümkün değildir.

Modern sanat ile ortaya çıkan geleneksel sanat anlayışından kopuş süreciyle birlikte hazır yapım malzemelerin Warhol, Duchamp, Picasso gibi pek çok farklı sanatçı tarafından çalışmalarında kullanılması söz konusudur. Bu süreçle birlikte geleneksel sanat anlayışının aksine doğru koşullar altında her türlü sıradan nesnenin sanat alanına dahil edilmesi mümkün olmuştur. Sanat olan ve olmayan nesne arasındaki farkı yaratan şey nesnenin özü ile alakalı değil bilakis bu tanımlama nesnenin sosyal bağlamına göre belirlenebilmektedir. Bu durumda sanat yapıtı olarak kabul edilecek nesneler arasındaki sınır ortadan kalkmış olmaktadır.

Uygun bir bağlama yerleştirilen her türlü nesne için sanat yapıtı olma potansiyeli söz konusudur. Brillo kutusu, kar küreği, bisiklet tekeri gibi sanat olarak kabul görmüş ve sanat tarihine geçmiş pek çok önemli eserler ile bu nesnelerin tıpa tıp seri üretim benzerleri arasındaki fark yalnızca kavramsal olarak vardır. Yani sanatçısı tarafından uygun bir sosyal bağlam içerisine yerleştirilerek göstergeye dönüştürülmesi, işlevlerinden soyutlanması, benzerlerinden farklılaştırılıp biricikleştirilmesi gibi süreçler sonrasında ortaya çıkan yapıtın sanat eseri olarak sanat dünyasına sunulması, sergilenmesiyle mümkün olmaktadır.

Bu durumda bir nesne belirli koşullar altında göstergeye dönüşme kapasitesine bağlı olarak yani göstergeye dönüşebildiği ve bu konumda kalabildiği sürece sanat yapıtı olabilme potansiyelini devam ettirmektedir. Göstergeye dönüşemeyen nesne yalnızca kendisi olarak kalır ve sanat alanına dahil olamaz. Gösterge sistemleri sanat alanının varlı̆ına işaret eder. Göstergeleşmiş bir nesne sanat yapıtı olma potansiyelini taşırken göstergeleşmiş bir mekân da içerisinde yer alan nesnelerin sanat olduğuna yönelik bir işaretleme/etiketleme imkanına sahip olmaktadır. Nesnelerin anlamları kendilerini sarmalayan sistemli kültürel kodlar ve değerler sisteminin yapısal bir ilişki sürecinde ortaya çıkarttı̆̆ı sosyal bağlama göre belirlenmektedir.

Nesnelerin gündelik yaşamda ait oldukları alanlar vardır. Bu alanlar nesnelerin kültürel mekânlarıdır. Bu kültürel mekânlar nesnelerin işlevleri ve bu işlev üzerinden nesneye atfedilen anlam doğrultusunda inşa edilmişlerdir. Nesne bu mekânda sorunsuzca kendi olarak konumlanmaktadır. Fakat nesne bu kültürel alanın dışına çıkartıldığında bağlamını kaybeder ve dolayısıyla göstergeye dönüşme imkânına kavuşur. Kültürel mekânının değişmesi bağlamının farklılaşmasına ve göstergeye dönüşerek kendisi dışındaki anlamların taşıyıcısı durumuna gelmesine neden olur.

Sıradan bir nesnenin kültürel mekânı dışında yeni bir bağlama yerleştirilerek gösterge sistemi üzerinden sanat alanına taşınması mümkündür. Bu süreç kusursuzca işleyen bir sistem olarak modern sanat anlayışı içerisinde yer almıştır. Bu sanat anlayışını çalışmalarında kullanan sanatçılardan biri de "Tracy Emin" dir. Sanatçı, kendi yatağını -kullanıımış dağııık haliyle- sergilenmek üzere galeriye yerleştirerek sanat alanına dahil etmiştir. Bu süreçte sıradan bir nesne olan yatak, kültürel mekânı yani uyuma, dinlenme alanı (yatak 
odası) dışarısına çıkartılarak yeni bir bağlama kavuşmuş böylece göstergeye dönüşmesi sağlanmıştır. Göstergeleşen yatak kendi işlevinden soyutlanmış ve sanatçısının ona yüklediği yeni anlamların yansıtıcısı haline gelerek bir sanat eserine dönüşmüştür. Böylece yatak olarak diğer benzerleriyle olan tüm benzerlikleri ortadan kalkmış ve sonuçta biricikleşmiştir.

Bu dönüşüm sürecinde yatak sanat nesnesi olarak etiketlenmektedir. Yani bulunduğu mekân bir sanat müzesidir ve sanat müzesinde sergilenen nesneler sanat eseri olarak algılanırlar. Müze bu süreçte harici gösterge sistemi üzerinden içerisinde yer alan yatağın sanat yapıtı olduğuna dair yani onu diğer nesnelerden ayıran kavramsal bir özelliğe sahip olduğuna dair bir etiketlemeyi gerçekleştirmektedir.

Ayrıca yatak müzeye sanatsal bir üretim süreci ve estetik veya sanatsal bir hedefi gerçekleştirmek amacıyla yerleştirilmiştir. Yatak, herhangi biri tarafından, sıradan bir amaçla ya da tesadüfi bir şekilde o alana yerleştirilmiş değildir. Sanatçısının kim olduğu, daha önce gerçekleştirdiği diğer sanatsal çalışmalar, faaliyetler, sanat alanındaki mevcut pozisyonu ve sanat kamusunun sanatçı ve çalışmalarına yönelik genel yaklaşımı bu sürecin yani sergi salonuna yerleştirilen nesnenin sanatsal bir çalışama olarak kabul görmesinde ve sanat eseri olarak etiketlenmesinde belirleyici olmaktadır.

Tracy Emin, yatağını müze dışında tren istasyonu gibi herhangi bir yerde sergilemesi halinde yatak yine sanat nesnesi olarak anlam kazanacaktır. Çünkü yatak kültürel mekânı dışında ve yeni bir bağlamda tren istasyonunda bulunmaktadır. Göstergeleşmiş ve sanatçısı tarafından sanatsal bir amaçla oraya yerleştirilmiştir. Tren istasyonunda sergilenmesinin müzeden farkı mekânın nesneyi sanat eseri olarak etiketleme sürecindeki rolüdür. Bu defa mekân sanat nesnesini değil sanat nesnesi mekânı sanat eseri sergilenen bir yer olarak işaret etmekte ve etiketlemektedir.

Tren istasyonu sanat eserlerine ev sahipliği yaptığı süre içerisinde göstergeye dönüşerek konvansiyonel bağlamından yani doğal olarak işlevi doğrultusunda algılanan bağlamından farklılaşmış ve müzenin sahip olduğu anlama benzer şekilde sanat eserlerinin sergilendiği bir mekâna dönüşmüştür. Mekânın kullanımına yönelik bu yeni yaklaşım mekânın anlamının genişlemesine neden olmuştur. Bu anlam genişlemesi sergileme eylemi süresince de devam eder. Ayrıca bu süreçte mekânın kültürel beleğinde yani önceden edindiği anlamlarda bir kayba neden olmaz.

Bu kavramsal yaklaşımlar sıradan bir nesnenin hangi süreçler sonrasında sanat alanına dahil olabildiğini göstermektedir. Bir nesne belirli koşulları sağladığı andan itibaren ve sürece sanat eserine dönüşme imkânına kavuşmaktadır. Bu süreci anlayabilmek sanat nesnesini, onu yapan sanatçıyı, müze gibi kurumların işlevini, sanat alanındaki yaklaşımları anlamamızı da kolaylaştırmaktadır. Ayrıca sanat müzelerinde her birimizin evinde bulunan sıradan bir nesne ile karşılaştığımızda aklımıza gelen bunun neresi sanat, bunu bende yapabilirim gibi düşüncelere bir cevap olmaktadır. Zira sanat alanı dışından birinin yatağını müzeye götürmesi durumunda yatak bir sanat yapıtına dönüşmeyecektir. Bir nesne sanat yapıtına ancak sanat alanına yönelik genel yaklaşımlar ve kabuller doğrultusunda ve bir sanatçının eylemi sonrasında kavramsal olarak dönüşebilmektedir.

Sanatçılar, sanat yapma konusunda genel kabul görmüş bir sosyal bağlamda yer almaktadırlar. Fakat sanatçılar dokunduklarını sanata çeviren kimseler değillerdir. Ürettikleri çalışmaların sanat olarak kabul görmesi için sanat adına üretilmiş olmaları gerekmektedir. Ünlü bir ressamın oturmak amacıyla ahşaptan yaptığı bir tabure sanat olarak kabul görmek durumunda değildir. Sanatçı bu tabureyi oturmak için üretmiştir ve işlevi budur. Üreticisinin ünlü bir sanatçı olması bu nesneyi doğrudan sanat yapmaz fakat sanatçıya ait olan bu taburenin bir hikayesi ve sosyal olarak başka anlamları olduğu muhakkaktır. Ünlü birinin elinden çıkmış olması ona özel bir anlam kazandırır. Bununla beraber sanat olarak kabul görmesi için bu amaçla üretilmiş olması ve uygun bir bağlama yerleştirilerek göstergeye dönüştürülmesi gerekmektedir. Aksi durumda nerde sergilenirse sergilensin nesne sanat eseri değil yalnızca kendisi olarak kalacaktır. 


\section{Kaynakça / References}

Alexander, J. C. \& Seidman, S. (2017). Kültür ve toplum. İstanbul: Boğaziçi Üniversitesi yayınları.

Atasoy, H. T. (2013). Insan neden sanat yapar. Ankara: Bilim ve gelecek kitaplığı.

Barnard, M. (2002). Sanat, tasarım ve görsel kültür. Ankara: Ütopya yayınları.

Başarır, N. (2009). Dolayısıyla sanat. İstanbul: Scala yayınları.

Danko, D. (2017). Sanat sosyolojisi. Ankara: Hece yayınları.

Danto, A. (2012). Sıradan olanın başkalaşımı. İstanbul: Ayrıntı yayınları.

Freeland, C. (2001). Sanat kuramı. Ankara: Dost kitapevi yayınları.

Heartney, E. (2008). Sanat ve bugün. İstanbul: Akbank yayınları.

Heidegger, M. (2007). Sanat eserinin kökeni. Ankara: De Ki yayınları.

Heinich, N. (2013). Sanat Sosyolojisi. İstanbul: Bağlam yayınları.

Kortun, V. (n.d.). 99 RG 002. İstanbul.

Kuspit, D. (2006). Sanatın Sonu. İstanbul: Metis yayınevi

Langer, S.K. (2012). Sanat problemleri. İstanbul: Mitos-Boyut yayınları.

Lenoir, B. (2004). Sanat yapıtı. İstanbul: YKY yayınları.

Levi-Strauss, C. (1994). Yaban düşünce. İstanbul: YKY yayınları.

Lynton, N. (2004). Modern sanatın öyküsü. İstanbul: Remzi kitapevi

Saehrendt, C. \& Kittl, S. T. (2014). Bunu ben de yaparım! Modern sanat kullanma kılavuzu. İstanbul: Ayrıntı yayınları.

Şahiner, R. (2015). Çağdaş sanatta temsiliyet krizi. Ankara: Ütopya yayınevi.

Williams, R. (1993). Kültür. Ankara: İmge kitapevi.

Woodward, I. (2016). Maddi kültürü anlamak. İstanbul: Türkiye İş Bankası kültür yayınları. 